International Journal of Biology, Pharmacy and Allied Sciences (IJBPAS)

'A Bridge Betuen caboratory and QRender'

WWW.ijbpas.com

\title{
HEPATOPROTECTIVE ACTIVITY OF WATER KEFIR
}

\section{ALIGITA W*, ALEX V, TAARAUNGAN SL AND SUSILAWATI E}

Department of Pharmacology, Faculty of Pharmacy, Bhakti Kencana University, Jl. Soekarno

Hatta 754 Bandung, Indonesia

*Corresponding Author: Widhya Aligita: E Mail: widhya.aligita@bku.ac.id

Received $9^{\text {th }}$ July 2020; Revised $7^{\text {th }}$ Aug. 2020; Accepted $6^{\text {th }}$ Sept. 2020; Available online $1^{\text {st }}$ June 2021

https://doi.org/10.31032/IJBPAS/2021/10.6.5493

\begin{abstract}
Acute liver failure is a type of liver disease in which the liver has decreased or even lost its function in a relatively short time. Previous research had shown that water kefir had strong antioxidant and anti-inflammatory activity. Therefore, this current study aimed to evaluate the ability of water kefir to prevent and treat acute liver failure. This experiment was conducted using two methods: the prevention and treatment of acute liver failure. In both methods, the inducing agent used was acetaminophen $2 \mathrm{~g} / \mathrm{kg}$ bw administrated orally. Water kefir was evaluated in 3 doses: $90 \mathrm{~mL} / \mathrm{kg} \mathrm{BW}, 180 \mathrm{~mL} / \mathrm{kg} \mathrm{BW}$, and $270 \mathrm{~mL} / \mathrm{kg} \mathrm{BW}$; with silymarine as the standard drug. The parameters were AST, ALT, ASP, and total protein level, and Manja Roenigk Histopathology Score. The results showed that in both methods, water kefir in all doses was able to significantly improve AST, ALT, ASP, and total protein level compared to the positive control. The improvement in these levels was also supported by the results of the histological score which also decreased. It means that there was an improvement in the level of liver necrosis. However, water kefir that showed comparable results to silymarine was a dose of $180 \mathrm{~mL} / \mathrm{kg} \mathrm{BW}$ for prevention and $270 \mathrm{~mL} / \mathrm{kg} \mathrm{BW}$ for the treatment of acute liver failure. It could be concluded that water kefir had the ability to prevent and treat acute liver failure caused by acetaminophen.
\end{abstract}

Keywords: acetaminophen, acute liver failure, hepatoprotective, water kefir \section{INTRODUCTION}

Liver is the largest organ in the human body and plays an important role in various

physiological processes, such as the metabolism of carbohydrates, lipids and 
amino acids; detoxification; blood clotting process; the body's defence process against infection; and others [1]. Acute liver failure is a type of liver disease in which the liver has decreased or even lost its function in a relatively short time. This condition was initially associated with drug-induced liver damage, although it could eventually be applied to other situations. Acute liver failure usually begins with acute liver injury characterized by a two to threefold increase in transaminases in patients without chronic liver disease [2, 3]. Acute liver failure can be caused by drug toxicity, viral and autoimmune hepatitis, and hepatic ischaemia [4]. Patients with acute liver failure show an increase in oxidative stress which is marked by high levels of SOD and lipid peroxidation [5].

Water kefir is a homemade fermented beverage. Water kefir has a long history and different names in each place, such as Tibi grain, California bees, African bees, Ale nuts, Balm of Gilead, Japanese Beer Seeds, or Sugary kefir grains [6-9]. Water kefir contains various microbial species such as Lactobacillus casei / paracasei, Lactobacillus harbinensis, Lactobacillus hilgardii,Bifidobacterium psychraerophilum/ crudilactis, Saccharomyces cerevisiae, and Dekkera bruxellensis. The main metabolites of fermented water kefir are ethanol and lactic acid; Glycerol, acetic acid, and mannitol are also produced in small quantities. Some aromatic and volatile compounds are also produced (relative to their threshold values) such as ethyl acetate, ethyl hexanoate, ethyl octanoate, isoamyl acetate, and ethyl decanoate [10]. Another research showed that kefir water had activity as an antioxidant, antihyperglycemia, antihyperlipidemia, antiobesity, anticancer, and activity in repairing disorders in the digestive tract [11-15]. Based on this explanation, this experiment aimed to evaluate the activity of water kefir in preventing and treating acute liver damage.

\section{MATERIALS AND METHODS}

\section{Materials}

Water kefir grain (purchased from Yogyakarta, Indonesia), sugar, dried fruit, rats aged 2 - 3 months and weighing 200$250 \mathrm{~g}$, silymarin, ethanol, formaldehyde buffer, sugar, hematoxylin-eosin, raisins, acetaminophen, reagent kits for the determination of AST, ALT, ALP and total protein.

\section{Preparation of Water Kefir}

The water kefir solution was made by fermentation, starting with the preparation of 100 grams of water kefir seeds, 60 grams of sugar, 2 grams of raisins and $1 \mathrm{~L}$ of aqua mineral distillate. The sugar was mixed with warm distilled water in a beaker glass, then put the water kefir seeds and raisins in the sugar solution. The beaker glass was 
closed using a thin cloth and the fermentation process was carried out for 48 hours at room temperature $\pm 25^{\circ} \mathrm{C}$. The filtrate was used for evaluation, while the kefir grain was reused for the next production [16].

\section{Water Kefir Activity in Liver Damage Prevention}

This evaluation aimed to evaluate the ability of water kefir to prevent liver damage due to cytotoxic agent administration, in this case was acetaminophen at a dose of $2 \mathrm{~g} / \mathrm{kg} \mathrm{BW}$ [17]. Rats were divided into 6 groups: the negative control group, the positive control group, the $200 \mathrm{mg} / \mathrm{kg} \mathrm{BW}$ silymarin group, and the water kefir group with doses of $90 \mathrm{~mL} / \mathrm{kg} \mathrm{BW}, 180 \mathrm{ml} / \mathrm{kg} \mathrm{BW}$, and $270 \mathrm{~mL} / \mathrm{kg} \mathrm{BW}$. The evaluation was carried out for 14 days, where the water kefir and acetaminophen were administered simultaneously. The parameters measured were AST, ALT, ALP, and total protein on days 0,7 , and 14 of treatment. At the end of the evaluation, the animals were sacrificed and their liver was isolated for histological analysis using the Manja Roenigk Histopathology Scoring [18].

\section{Water Kefir Activity in Liver Damage Treatment}

This evaluation aimed to evaluate the ability of water kefir to treat and improve liver damage due to cytotoxic agent administration, in this case was acetaminophen at a dose of $2 \mathrm{~g} / \mathrm{kg} \mathrm{BW}$ [17]. In this evaluation, the procedure was divided into 2 stages: the induction stage and the treatment stage. At the induction stage, animals were divided into 2 groups: the group that was not induced (negative control) and the group that was induced. Induction was carried out for 14 days using acetaminophen $2 \mathrm{~g} / \mathrm{kg}$ BW. The induced rats were divided into 5 groups, that were the positive control group, the silymarin group $200 \mathrm{mg} / \mathrm{kg} \mathrm{BW}$, and the water kefir group with the dose of $90 \mathrm{~mL} / \mathrm{kg}, 180 \mathrm{ml} /$ $\mathrm{kg}$, and $270 \mathrm{~mL} / \mathrm{kg} \mathrm{BW}$. The treatment was carried out for 14 days. The parameters measured were AST, ALT, ALP, and total protein at before treatment, after induction, and after treatment. At the end of the test, the animal was sacrificed and the liver was isolated for histological analysis using the Manja Roenigk Histopathology Scoring [18].

\section{RESULTS AND DISCUSSION}

The results of evaluation of water kefir activity in preventing and treating liver damage due to hepatotoxic agent were shown in Table 1-4.

Tables 1, 2, 3, and 4 showed that all animals were in a homogeneous state before given treatment. In the prevention method, administration of high doses of paracetamol caused a significant increase in 
the AST, ALT, and ALP level of the positive control group when compared to all other groups on days 7 and 14 . Significant changes also occurred in total protein level, where the total protein in the positive control group indicate a significantly lower number compared to the other groups. While in the treatment method, acetaminophen administration at a dose of $2 \mathrm{~g} / \mathrm{kg}$ BW for 7 days caused significant changes in all parameters. AST, ALT, and ALP level were significantly increased in all induced groups compared to the negative control group. Meanwhile, the total protein level decreased significantly. It indicate that the administration of paracetamol at dose of 2 $\mathrm{g} / \mathrm{kg}$ bw could damage the physiology of the liver.

Acetaminophen is an analgesic and antipyretic drug that is safe to use in therapeutic doses. However, in high doses, it can cause liver damage. From the result above, we could see that paracetamol was able to induce liver damage, characterized by increased levels of AST, ALT, ALP, and decreased levels of total protein in the positive control group in both methods used. Acetaminophen-induced hepatotoxicity begins with the formation of the reactive metabolite N-acetyl-pbenzoquinone imine (NAPQI), which results in reduced cellular glutathione and the formation of additional proteins in mitochondrial proteins. These events lead to mitochondrial oxidative and nitrosative stress, which is accompanied by activation of c-jun N-terminal kinase (JNK) and translocation to mitochondria. This further amplifies mitochondrial oxidantive stress, leading to translocation of Bax and dynamin related protein 1 (Drp1) to the mitochondria, which induces mitochondrial fission and induces mitochondrial membrane permeability transition (MPT). These induction triggers the release of intermembrane proteins such as apoptosis inducing factor (AIF) and endonuclease $G$ into the cytosol and their translocation to the nucleus, causing fragmentation of nuclear DNA and ultimately activating the regulated necrosis [19].

Water kefir administration at various doses for 14 days resulted in improvements in the level of AST, ALT, ALP, and total protein, both in the prevention and treatment methods, which was marked by significant differences in the parameters level of the treated group and the positive control group. However, the group that showed hepatoprotecvtive activity comparable to silymarine as the standard drug on all parameters was the $270 \mathrm{~mL} / \mathrm{kg}$ bw water kefir group. It could be interpreted that the administration of silymarine and water kefir was able to prevent and treat damage 
caused by the toxic effect of high doses of acetaminophen. This was supported by the result of the histological analysis which showed a significant difference from the liver histology scores calculated using the Manja Roenigk measurement method, as shown in Table 5.

Table 1: AST level

\begin{tabular}{|l|c|c|c|c|c|c|}
\hline \multirow{2}{*}{\multicolumn{1}{c}{ Groups }} & \multicolumn{2}{c}{ AST level at days- (Preven tion Method) } & \multicolumn{3}{c|}{ AST level at days- (Treatment Method) } \\
\cline { 2 - 7 } & $\mathbf{0}$ & $\mathbf{7}$ & $\mathbf{1 4}$ & $\mathbf{0}$ & $\mathbf{7}$ & $\mathbf{2 1}$ \\
\hline Negative control & $113.4 \pm 11.3$ & $123.2 \pm 4.4^{*}$ & $117.8 \pm 2.8^{*}$ & $113.4 \pm 11.3$ & $121.0 \pm 5.7^{*}$ & $117.8 \pm 2.8^{*}$ \\
\hline Positive control & $120.2 \pm 6.8$ & $204.2 \pm 6.1$ & $219.6 \pm 3.4 \#$ & $115.6 \pm 8.6$ & $207.0 \pm 4.0$ & $219.0 \pm 6.9 \#$ \\
\hline Silymarine $200 \mathrm{mg} / \mathrm{kg}$ bw & $118.0 \pm 15.6$ & $125.0 \pm 12.2^{*}$ & $118.4 \pm 3.1^{*}$ & $119.4 \pm 12.3$ & $205.6 \pm 8.3$ & $121.2 \pm 3.1^{*}$ \\
\hline Water kefir $90 \mathrm{~mL} / \mathrm{kg} \mathrm{bw}$ & $121.8 \pm 5.5$ & $129.4 \pm 5.9^{*}$ & $125.6 \pm 2.1^{*} \#$ & $122.6 \pm 8.1$ & $209.0 \pm 8.0$ & $130.0 \pm 5.1^{* \#}$ \\
\hline Water kefir $180 \mathrm{~mL} / \mathrm{kg}$ bw & $117.8 \pm 9.8$ & $129.4 \pm 7.3^{*}$ & $121.8 \pm 2.8^{*}$ & $118.6 \pm 4.9$ & $208.8 \pm 6.7$ & $128.2 \pm 4.1^{* \#}$ \\
\hline Water kefir $270 \mathrm{~mL} / \mathrm{kg}$ bw & $114.6 \pm 8.1$ & $124.6 \pm 2.1^{*}$ & $119.4 \pm 1.7^{*}$ & $119.2 \pm 6.6$ & $206.8 \pm 8.6$ & $125.8 \pm 5.1^{*}$ \\
\hline
\end{tabular}

Note: Data are presented as mean \pm SD, * means significantly different compared to the positive control group, \# means significantly different compared to the silymarine group, $p<0.05, n=5$ mice/group.

Table 2: ALT level

\begin{tabular}{|l|c|c|c|c|c|c|}
\hline \multirow{2}{*}{ Groups } & \multicolumn{2}{c|}{ ALT level at days- (Prevention Method) } & \multicolumn{3}{c}{ ALT level at days- (Treatment Method) } \\
\cline { 2 - 7 } & $\mathbf{0}$ & $\mathbf{7}$ & $\mathbf{1 4}$ & $\mathbf{0}$ & $\mathbf{7}$ & $\mathbf{2 1}$ \\
\hline Negative control & $68.2 \pm 1.9$ & $72.6 \pm 2.7^{*}$ & $69.8 \pm 1.3^{*}$ & $68.2 \pm 1.9$ & $72.2 \pm 1.9^{*}$ & $69.8 \pm 1.3^{*}$ \\
\hline Positive control & $65.8 \pm 4.0$ & $144.6 \pm 8.4$ & $151.8 \pm 4.2 \#$ & $66.6 \pm 4.4$ & $188.2 \pm 4.4$ & $204.0 \pm 5.8 \#$ \\
\hline Silymarine $200 \mathrm{mg} / \mathrm{kg} \mathrm{bw}$ & $64.6 \pm 3.4$ & $75.4 \pm 3.6^{*}$ & $68.6 \pm 2.4^{*}$ & $69.4 \pm 5.9$ & $183.0 \pm 4.4$ & $70.2 \pm 3.7^{*}$ \\
\hline Water kefir $90 \mathrm{~mL} / \mathrm{kg} \mathrm{bw}$ & $67.6 \pm 3.1$ & $76.4 \pm 3.8^{*}$ & $73.6 \pm 2.3^{*} \#$ & $68.6 \pm 5.7$ & $183.0 \pm 4.3$ & $76.2 \pm 1.9^{*} \#$ \\
\hline Water kefir $180 \mathrm{~mL} / \mathrm{kg} \mathrm{bw}$ & $66.6 \pm 2.7$ & $74.6 \pm 3.1^{*}$ & $70.2 \pm 3.0^{*}$ & $64.0 \pm 1.6$ & $181.4 \pm 6.7$ & $73.6 \pm 3.4^{*}$ \\
\hline Water kefir $270 \mathrm{~mL} / \mathrm{kg} \mathrm{bw}$ & $62.4 \pm 2.7$ & $75.2 \pm 3.4^{*}$ & $67.2 \pm 2.6^{*}$ & $65.8 \pm 6.0$ & $180.8 \pm 6.6$ & $71.0 \pm 2.5^{*}$ \\
\hline
\end{tabular}

Note: Data are presented as mean $\pm \mathrm{SD}, *$ means significantly different compared to the positive control group, \# means significantly different compared to the silymarine group, $p<0.05, n=5$ mice/group.

Table 3: ALP level

\begin{tabular}{|l|c|c|c|c|c|c|}
\hline \multirow{2}{*}{ Groups } & \multicolumn{2}{c}{ ALP level at days- (Prevention Method) } & \multicolumn{3}{c}{ ALP level at days- (Treatment Method) } \\
\cline { 2 - 7 } & $\mathbf{0}$ & $\mathbf{7}$ & $\mathbf{1 4}$ & $\mathbf{0}$ & $\mathbf{7}$ & $\mathbf{2 1}$ \\
\hline Negative control & $110.6 \pm 8.0$ & $111.8 \pm 6.4^{*}$ & $109.4 \pm 2.4^{*}$ & $110.6 \pm 8.0$ & $111.8 \pm 6.4^{*}$ & $109.4 \pm 2.4^{*}$ \\
\hline Positive control & $112.0 \pm 7.0$ & $234.4 \pm 4.7$ & $235.0 \pm 5.4 \#$ & $113.2 \pm 4.3$ & $240.6 \pm 2.4$ & $254.8 \pm 4.1 \#$ \\
\hline Silymarine $200 \mathrm{mg} / \mathrm{kg} \mathrm{bw}$ & $108.4 \pm 6.0$ & $111.0 \pm 5.3^{*}$ & $110.0 \pm 2.9^{*}$ & $116.2 \pm 6.1$ & $241.0 \pm 4.7$ & $112.4 \pm 3.0^{*}$ \\
\hline Water kefir $90 \mathrm{~mL} / \mathrm{kg} \mathrm{bw}$ & $114.2 \pm 8.1$ & $117.0 \pm 6.6^{*}$ & $112.4 \pm 4.8^{*}$ & $116.2 \pm 4.4$ & $239.2 \pm 7.5$ & $120.6 \pm 3.3^{*} \#$ \\
\hline Water kefir $180 \mathrm{~mL} / \mathrm{kg} \mathrm{bw}$ & $110.2 \pm 5.9$ & $113.6 \pm 3.7^{*}$ & $110.6 \pm 2.4^{*}$ & $114.0 \pm 9.3$ & $238.0 \pm 2.5$ & $114.6 \pm 6.9^{*}$ \\
\hline Water kefir $270 \mathrm{~mL} / \mathrm{kg} \mathrm{bw}$ & $101.0 \pm 1.0$ & $112.8 \pm 2.8^{*}$ & $108.6 \pm 2.4^{*}$ & $114.6 \pm 7.1$ & $238.0 \pm 11.4$ & $113.4 \pm 8.3^{*}$ \\
\hline
\end{tabular}

Note: Data are presented as mean $\pm \mathrm{SD}$, * means significantly different compared to the positive control group, \# means significantly different compared to the silymarine group, $p<0.05, n=5$ mice/group.

Table 4: Total protein level in liver failure prevention method

\begin{tabular}{|c|c|c|c|c|c|c|}
\hline \multirow[t]{2}{*}{ Groups } & \multicolumn{3}{|c|}{$\begin{array}{c}\text { Total protein level at days- (Prevention } \\
\text { Method) }\end{array}$} & \multicolumn{3}{|c|}{$\begin{array}{c}\text { Total protein level at days- (Treatment } \\
\text { Method) }\end{array}$} \\
\hline & $\mathbf{0}$ & 7 & 14 & $\mathbf{0}$ & 7 & 21 \\
\hline Negative control & $6.39 \pm 0.29$ & $6.79 \pm 0.14 *$ & $6.52 \pm 0.07 *$ & $6.4 \pm 0,3$ & $6.8 \pm 0.1^{*}$ & $6.5 \pm 0.1 *$ \\
\hline Positive control & $6.65 \pm 0.45$ & $5.37 \pm 0.28$ & $4.33 \pm 0.06 \#$ & $6.7 \pm 0.3$ & $5.0 \pm 0.1$ & $4.9 \pm 0.04 \#$ \\
\hline Silymarine $200 \mathrm{mg} / \mathrm{kg}$ bw & $6.60 \pm 0.22$ & $6.64 \pm 0.09 *$ & $6.71 \pm 0.05^{*}$ & $6.8 \pm 0.4$ & $5.0 \pm 0.1$ & $6.8 \pm 0.1 *$ \\
\hline Water kefir $90 \mathrm{~mL} / \mathrm{kg}$ bw & $6.51 \pm 0.33$ & $4.92 \pm 0.09 *$ & $5.61 \pm 0.22 * \#$ & $6.5 \pm 0.3$ & $5.1 \pm 0.1$ & $6.1 \pm 0.1 * \#$ \\
\hline Water kefir $180 \mathrm{~mL} / \mathrm{kg}$ bw & $6.45 \pm 0.31$ & $6.07 \pm 0.07 *$ & $6.21 \pm 0.20 * \#$ & $6.3 \pm 0.3$ & $5.0 \pm 0.2$ & $6.5 \pm 0.4 * \#$ \\
\hline Water kefir $270 \mathrm{~mL} / \mathrm{kg}$ bw & $6.47 \pm 0.30$ & $6.59 \pm 0.07 *$ & $6.60 \pm 0.05^{*}$ & $6.7 \pm 0.2$ & $5.1 \pm 0.1$ & $6.7 \pm 0.1^{*}$ \\
\hline
\end{tabular}

Note: Data are presented as mean $\pm \mathrm{SD}, *$ means significantly different compared to the positive control group, \# means significantly different compared to the silymarine group, $\mathrm{p}<0.05, \mathrm{n}=5 \mathrm{mice} / \mathrm{group}$. 
Table 5: Manja Roenigk histological score

\begin{tabular}{|l|c|c}
\hline \multicolumn{1}{c}{ Groups } & Prevention Method & Treatment Method \\
\hline Negative control & $1.15 \pm 0.16^{*}$ & $1.15 \pm 0.09^{*}$ \\
\hline Positive control & $3.26 \pm 0.24 \#$ & $2.85 \pm 0.06 \#$ \\
\hline Silymarine $200 \mathrm{mg} / \mathrm{kg} \mathrm{bw}$ & $1.38 \pm 0.14^{*}$ & $1.21 \pm 0.18^{*}$ \\
\hline Water kefir $90 \mathrm{~mL} / \mathrm{kg} \mathrm{bw}$ & $1.76 \pm 0.05^{*} \#$ & $1.64 \pm 0.07^{*} \#$ \\
\hline Water kefir $180 \mathrm{~mL} / \mathrm{kg}$ bw & $1.57 \pm 0.05^{*}$ & $1.47 \pm 0.05^{*} \#$ \\
\hline Water kefir $270 \mathrm{~mL} / \mathrm{kg}$ bw & $1.34 \pm 0.08^{*}$ & $1.18 \pm 0.03^{*}$ \\
\hline
\end{tabular}

Note: Data are presented as mean $\pm \mathrm{SD}$, * means significantly different compared to the positive control group, \# means significantly different compared to the silymarine group, $p<0.05, n=3$ mice/group.

Table 5 showed that the lowest histopathological score was in the negative control group and the highest was in the positive control group. The score close to the number 1 indicates normal conditions, while the score closer to the 4 indicates the elevated number of cell deaths. The score in the negative control group differed significantly from the positive control group. These meant that acetaminophenled to the histological damage inanimalmodel's liver. Meanwhile, the silymarine and water kefir groups showed a histological score closer to 1 , although only the silymarine group and the water kefir group at dose of $180 \mathrm{~mL} / \mathrm{kg}$ bw in the prevention method and $270 \mathrm{~mL} / \mathrm{kg}$ bw in the treatment method showed values that were not significantly different from the negative control group.

The result showed that water kefir at all doses was able to improve acute liver failure condition either as prevention or treatment, which was characterized by significant improvement of AST, ALT, ALP, and total protein compared to the positive control group. Elevation in the dose indicated an increase in the intensity of the hepatoprotective effect. However, doses of $180 \mathrm{mg} / \mathrm{kg}$ bw rats and $270 \mathrm{mg} /$ $\mathrm{kg}$ bw rats showed a hepatoprotective effect comparable to silymarineas prevention and treatment, respectively. The ability of water kefir to treat acute liver failure had also been shown by other studies [20].

If we look at the pathophysiology of acute liver failure, free radicals and inflammation play an important role throughout the process. Patients with acute liver failure show an increase in oxidative stress which is characterized by high levels of SOD and lipid peroxidation [5]. Therefore, drugs with strong antioxidant and antiinflammatory activity, as shown by water kefir, have the potential to act as a drug for acute liver failure [16]. The liver plays a role in the metabolism of various substances that have the potential to produce free radicals. However, the body is able to produce endogenous antioxidants that are able to maintain a balance of 
oxidative level in the liver. When oxidative compounds are more dominant, there will be conditions of oxidative stress which can cause damage such as lipid peroxidation, DNA oxidative damage, and protein damage [21]. Increased oxidative stress will also trigger an inflammatory response through the release of cytokines such as transforming growth factor- $\beta$ (TGF- $\beta$ ), interleukin-6 (IL-6), and tumor necrosis factor- $\alpha$ (TNF- $\alpha)$. Cytokines play an important role in cytokines mediate hepatic inflammation, apoptosis and necrosis of liver cells, cholestasis and fibrosis. Among the various types of cytokines, TNF- $\alpha$ has been shown to play a key factor in various aspects of liver damage [22]. A high systemic inflammatory response can ultimately lead to organ failure and death [23]. Several substances that have antioxidant activity have been shown to have the ability to repair liver damage, such as curcumin, coffee, quercetin, silymarine, and others [24].

Liver disease is also frequently associated with the gut microbiome. Our bodies contain approximately 100 trillion microbes consisting of bacteria, viruses, and eukaryotes, each of which interacts with each other, including with us as hosts $[25,26]$. Most of the microbiome is located in the intestine and plays an important role in immune function and metabolic function which ultimately affects nutrition and body physiology [26, 27]. The metabolites produced by the gut microbiome and their interactions with the host affect normal physiology and the body's ability to withstand disease. The disorder in this condition is called dysbiosis and can affect health [28]. Genetics, age and external factors such as diet, exposure to toxic substances can affect the gut balance of the microbiome $[22,28]$.

The condition dysbiosis is also found in patients with liver damage. Qualitative changes (imbalance between harmful and beneficial microbiome) and quantitative (changes in the total microbiome) of the gut microbiome affect liver health [28]. These changes can cause disturbances in the composition of the product produced by the microbiome. In addition, dysbiosis can also cause intestinal inflammation, intestinal barrier damage, and translocation of microbial products [29]. Consumption of probiotics, especially those containing lactic acid bacteria, can improve the balance of the composition of the gut microbiome [30]. Water kefir contains various lactic acid microbial species [10]. Consumption of kefir, either milk kefir or water kefir, had also been shown to improve dysbiosis [31, 32, 33]. Another role of the gut microbiome is its activity in modulating the metabolism of amino acids 
and glutathione in the host [34]. Liver damage due to drugs, alcohol, diet, and pollutants, one of which is characterized by glutathione homeostasis disorders [35]. Glutathione is a tripeptide compound composed of glutamate, cysteine and glycine. Glutathione functions as a cellular antioxidant and protects cells from oxidative damage. The balance between reactive oxygen species (ROS) and glutathione in hepatocytes is critical in various pathogenesis of liver disease. The decrease in the mitochondrial glutathione levels will induce mitochondrial ROS and will eventually lead to cell death [36].

\section{CONCLUSION}

Water kefir had the ability to prevent and treat acute liver failure caused by acetaminophen.

\section{ACKNOWLEDGEMENT}

This research was fully funded by Ministry of Research and Technology/ National Research and Innovation Agency, Republic of Indonesia.

\section{REFERENCES}

[1] Sivakrishnan S. Liver Diseases An Overview. World Journal of Pharmacy and Pharmaceutical Sciences 2019; 8(1):1385-95.

[2] Larson AM, Polson J, Fontana RJ,Davern TJ, Lalani E, Hynan LS, Reisch JS, SchiØdt FV, Ostapowicz G, Shakil AO, Lee WM.
Acetaminophen-induced acute liver failure: Results of a United States multicenter, prospective study. Hepatology2005; 42(6): 1364-72.

[3] European Association for the Study of the Liver. EASL Clinical Guidelines on the Management of Acute (Fulminant) Liver Failure. Journal of Hepatology 2017; 66:1047-81.

[4] Stravitz RT, Lee WM. Acute Liver Failure. The Lancet 2019; 394(10201):869-81.

[5] Bhatia V, Bhardwaj P, Elikkottil J, Batra J, Saraya A. A 7-day profile of oxidative stress and antioxidant status in patients with acute liver failure. Hepatology International $2008 ; \quad 2(4): \quad 465-70$. doi:10.1007/s12072-008-9098-6

[6] Lutz ML. Recherches biologiques sur la constitution du Tibi. Bulletin de la Societe Mycologique de France 1899; 15: 68-72.

[7] Pidoux M. The microbial flora of sugary kefir grain (the gingerbeer plant): bio- synthesis of the grain from Lactobacillus hilgardii producing a polysaccharide gel. MIRCEN Journal 1989; 5: 223-38.

[8] Pidoux M, de Ruiter GA, Brooker BE, Colquhoun IJ, Morris VJ. Microscopic and chemical studies 
of a gelling polysaccharide from Lactobacillus hilgardii.

Carbohydrate Polymers 1990; 13:351-62.

[9] Kebler LF. California bees. Journal of the American Pharmaceutical Association 1921; 10 (12): 939-43.

[10] Laureys and De Vuyst. Water kefir as a promising low-sugar probiotic fermented beverage. Archives of Public Health 2014; 72(Suppl 1):P1.

[11] Muneer Alsayadi MS, Al Jawfi Y, Belarbi M, Sabri FZ. Antioxidant Potency of Water Kefir. Journal of Microbiology, Biotechnology, and Food Science 2013; 2(6): 2444-7.

[12] Muneer Alsayadi MS, Al Jawfi Y, Belarbi M, Soualem-Mami Z, Merzouk H, Sari DC, Sabri F, Ghalim M. Evaluation of antihyperglycemic and antihyperlipidemic activities of water kefir as probiotic on streptozotocin-induced diabetic wistar rats. Journal of Diabetes Mellitus 2014; 4: 85-95.

[13] Koh WY, Uthumporn U, Rosma A, Effarizah ME, Wan Rosli WI. Assessment of yeast, acetic and lactic acid bacteria isolated from water kefir grains and theis application as starter culture in the production of fermented pumpkinbased water kefir beverages in improving gastrointestinal tract digestive tolerance and inhibition against alpha-glucosidase. International Food Research Journal 2019; 26(2): 429-39.

[14] Bourrie BCT, Cotter PD, Willing BP. Traditional Kefir Reduces Weight Gain and Improves Plasma and Liver Lipid Profiles More Successfully than a Commercial Equivalent in a Mouse Model of Obesity. Journal of Functional Foods 2018; 46: 29-37.

[15] Hatmal MM, Nuirat A, Zihlif MA, Tahat MO. Exploring the influence of culture conditions on kefir's anticancer properties. Journal of Dairy Science 2018; 101(5): 3771-7.

[16] Aligita W, Tarigan PN, Susilawati E. Antiinflamatory and Antioxidant Activity of Water Kefir. International Journal of Biology, Pharmacy, and Allied Sciences 2020; 9(1): 2454-64.

[17] Rajasekaran A, Periyasamy $M$. Hepatoprotective effect of ethanolic extract of Trichosanthes lobate on paracetamol-induced liver toxicity in rats. Chinese Medicine 2012(7): 12. 
[18] Situmorang PC, Ilyas S, Hutahaean S, Rosidah. Effect of nanoherbal andaliman (Zanthoxylum acanthopodium) and extra virgin olive oil combination on preeclamptic rats liver histology. Macedonian Journal of Medical Sciences 2019; 7(14): 2226-31.

[19] Ramachandran A, Jaeschke $H$. Mechanisms of acetaminophen hepatotoxicity and their translation to the human pathophysiology. J Clin Transl Res. 2017; 3(Suppl 1):157-169. doi:10.18053/jctres.03.2017S1.00 2

[20] Eunice B, Aspiras E, Frances R, Flores AC, Pareja MC. Hepatoprotective effect of Fermented Water Kefir on Sprague-Dawley rats (Rattus norvegicus) induced with sublethal dose of Acetaminophen. International Journal of Current Science 2015; 17: 18-28.

[21] Yoshikawa T, Naito Y. What is oxidative stress?.JMAJ 2002; 45(7): 271-6.

[22] Tilg H. Cytokines and liver diseases. Canadian Journal of Gastroenterology 2001; 15(10): 661-8. doi:10.1155/2001/746736
[23] Laleman W, Claria J, Van der Merwe S, Moreau R, Trebicka J. Systemic Inflammation and Acuteon-Chronic Liver Failure: Too Much, Not Enough. Canadian Journal of Gastroenterology and Hepatology 2018; 2018: 1027152.

[24] Casas-Grajales S, Muriel P. Antioxidants in liver health. World Journal of Gastrointestinal Pharmacology and Therapeutics. 2015; 6(3): 59-72.

doi:10.4292/wjgpt.v6.i3.59

[25] Ley RE, Peterson DA, Gordon JI. Ecological and evolutionary forces shaping microbial diversity in the human intestine. Cell. 2006; 124(4): 837-848.

doi:10.1016/j.cell.2006.02.017

[26] Clemente JC, Ursell LK, Parfrey LW, Knight R. The impact of the gut microbiota on human health: an integrative view. Cell. 2012; 148(6): 1258-1270. doi:10.1016/j.cell.2012.01.035

[27] Qin, J., Li, R., Raes, J. et al. A human gut microbial gene catalogue established by metagenomic sequencing. Nature 464, 59-65 (2010).

https://doi.org/10.1038/nature0882 1

[28] Llorente C, Schnabl B. The gut microbiota and lover disease. 
Cellular and Molecular

Gastrornterology and Hepatology 2015; 1(3): 275-84.

[29] Schnabl B, Brenner DA. Interactions Between the Intestinal Microbiome and Liver Diseases. Gastroenterology 2014; 146(6): 1513-24.

https://doi.org/10.1053/i.gastro.20 $\underline{14.01 .020}$

[30] Hemarajata P, Versalovic J. Effects of probiotics on gut microbiota: mechanisms of intestinal immunomodulation and neuromodulation. Therap Adv Gastroenterol. 2013;6(1):39-51 . doi:10.1177/1756283X12459294

[31] Toscano M, De Grandi R, Miniello VL, Mattina R. Ability of Lactobacillus kefiri LKF01 (DSM32079) to colonize the intestinal environment and modify the gut microbiota composition of healthy individuals. Digestive and Liver Disease 2017; 49: 261-7.

[32] Kim, D., Chon, J., Kim, H. et al. Modulation of intestinal microbiota in mice by kefir administration. Food Sci Biotechnol 24, 1397-1403 (2015). https://doi.org/10.1007/s10068$\underline{015-0179-8}$
[33] Bellikci-Koyu E, Sarer-Yurekli BP, Akyon Y, Aydin-Kose F, Karagozlu C, Ozgen AG, Brinkmann A, Nitsche A, Ergunay K, Yilmaz E, Buyuktuncer Z. Effects of regular kefir comsumption on gut microbiota in patients with metabolic syndrome: A parallel-group, randomized, controlled study. Nutrients 2019; 11: 2089.

[34] Mardinoglu A, Shoaie S, Bergentall M, Ghaffari P, Zhang C, Larsson E, Backhed F, Nielsen J. The Gut Microbiota Modulates Host Amino Acid and Glutathione Metabolism in Mice. Molecular Systems Biology 2015; 11:834.

[35] Chen Y, Dong H, Thompson DC, Shertzer HG, Nebert DW, Vasiliou V. Glutathione defense mechanism in liver injury: insights from animal models. Food Chem Toxicol. 2013; 60: 38-44. doi:10.1016/j.fct.2013.07.008

[36] Yuan L, Kaplowitz N. Glutathione in liver diseases and hepatotoxicity. Molecular Aspect of Medicine 2009; 30(2009): 2941. 